\title{
PENGARUH PEMBERIAN ANKLE BALANCE STRATEGY EXERCISE MENINGKATKAN KESEIMBANGAN SISWA PUTRA PESERTA EKSTRAKURIKULER ATLETIK LOMPAT JAUH
}

\author{
Devi AryaWati ${ }^{1}$, I Made Yoga Parwata ${ }^{2}$, Luh Putu Ayu Vitalistyawati ${ }^{3}$ \\ 1,2,3 Program Studi Fisioterapi, Universitas Dhyana Pura \\ Denpasar, Indonesia
}

e-mail: Ayakkdev@gmail.com, yogaparwata@undhirabali.ac.id, Ayuvita@undhirabali.ac.id

\begin{abstract}
Abstrak
Olahraga lompat jauh merupakan cabang olahraga atletik, olahraga atletik ini sering disebut "ibu olahraga karena terdiri dari gerak dasar manusia yang melibatkan gerakan jalan, lari, lompat dan lempar. Olahraga lompat jauh adalah salah satu olahraga prestasi. Olahraga ini memiliki empat fase yaitu awalan, tolakan, melayang dan mendarat. Pada lompat jauh ini fase mendarat merupakan fase terpenting. Komponen fisik yang sangat dibutuhkan dalam fase mendarat yaitu keseimbangan. Keseimbangan dapat ditingkatkan melalui latihan ankle balance strategy exercise. Penelitian ini bertujuan untuk mengetahui latihan ankle balance strategy exercise meningkatkan keseimbangan pada siswa putra ekstrakurikuler atletik lompat jauh di SMKN1 Denpasar. Metode yang digunakan dalam penelitian ini adalah Pre-Experimental. One-Group Pretest- Post test Design, bertempat di Lapangan Lumintang, dengan jumlah sampel penelitian sebanyak 10 orang. Latihan dilakukan selama 12 kali pertemuan, frekuensi 3 kali seminggu. Instrumen pengumpulan data yang digunakan strokstand test untuk mengukur keseimbangan. Data dianalisis dengan menggunakan pairedt-test dengan tingkat siginifikan $0.000(p \leq 0.05)$. Hasil analisis data bahwa latihan ankle balance strategy exercise bermakna secara statistik dan dapat meningkatkan keseimbangan sebesar $20,51 \%$. siswa putra peserta ekstrakurikuler atletik lompat jauh di SMKN1 Denpasar
\end{abstract}

Kata Kunci: lompat, jauh, fase, pendaratan, keseimbangan.

\begin{abstract}
Long jump sport is an athletic sport, which is usually called the "mother of sports" because it consists of basic human movements that involve walking, running, jumping and throwing. Long jump is a sport of achievement. This sport has four phases, namely starting, repulsing, hovering and landing. In this long jump, the landing phase is the most important phase. Balance is the physical component that is needed in the landing phase. Balance can be improved by the ankle balance strategy exercise. This study aims to determine the ankle balance strategy exercise to improve balance in male students in extracurricular long jump athletics at SMKN1 Denpasar. The method used in this research is Pre-Experimental. OneGroup Pretest-Post test Design and located in Lumintang Field, with a total sample of 10 people. The exercise was carried out for 12 meetings, the frequency was 3 times a week. The data collection instrument used was the stroke stand test to measure balance. Data were analyzed using paired-test with a significance level of 0.000 ( $p \leq 0.05)$. The results of data analysis showed that the ankle balance strategy exercise was statistically significant and could improve balance by $20.51 \%$. male students participating in long jump athletic extracurricular at SMKN1 Denpasar
\end{abstract}

Keywords: jump, long, phase, landing, balance.

\section{PENDAHULUAN}

Lompat jauh merupakan salah satu nomor dari cabang atletik yang selalu dipertandingkan pada setiap multi event olaraga baik tingkat daerah, nasional dan internasional. Dimana gerakan dasar dari lompat jauh terangkai dalam beberapa fase gerakan yaitu: fase awalan, fase tolakan, fase melayang, dan fase mendarat(Sidik, 2010). Lompat jauh merupakan suatu gerakan melompat yang menggunakan tumpuan pada satu kaki yang terkuat untuk mencapai jarak terjauh. Lompat jauh adalah gerakan mengangkat kaki ke atas dan ke depan untuk membawa titik berat badan melayang diudara, dengan tolakan 
yang kuat pada satu kaki untuk mencapai jarak terjauh dan pada waktu fase medarat dimulai dengan posisi tungkai kaki fleksi hip dan fleksi knee diikuti dengan posisi fleksi lumbal dengan disertai gerakan plantar fleksi saat mendarat dan diakhir gerakan terjadi gerakan dorso fleksi diikuti plantar fleksi, dimana pada fase pendaratan mempunyai tujuan untuk memperkecil hilangnya jarak lompatan. Lompat jauh merupakan gerakan me-lompat yang diawali dengan gerakan horizontal dan diubah ke gerakan vertical dengan jalan melakukan tolakan dengan satu kaki terkuat untuk mencapai jarak yang jauh(Meriyanto et al., 2016).

Pada nomor lompat jauh pada fase mendarat adalah hal terpenting yang harus dicapai oleh atlet lompat jauh karena penilaian lompatan memperhitungkan jauh lompatan. Diukur dari Jarak dari papan tolakan sampai pada titik tubuh mendarat.Selain kondisi fisik yang baik seorang atlet lompat jauh harus memiliki komponen lain seperti keseimbangan(Sumartiningsih, 2012). Peranan keseimbangan pada lompat jauh sangat pentin . Pada saat awalan dan pada saat tumpuan dan melayang diudara, keseimbangan harus terjaga agar lompatan menjadi sempurna.(Sehuddin, 2017). Keseimbangan harus dimiliki oleh seseorang untuk tetap berada dalam keadaan seimbang dan menyesuaikan diri terhadap gravitasi(Putu et al., 2018)

Kemampuan menjaga keseimbangan pada atlet lompata jauh pada saat mendarat sangat diperlukan dan berperan besara dalam menentukan jarak lompatan akhir, karena dengan keseimbangan yang kurang seorang atlet lompat jauh bisa terjerembab kebelakang akibat kurangnya keseimbangna saat mendarat yang berakibat hasil lompatan menjadi lebih dekat. Kemampuan menjaga keseimbangan bergantung pada stabilitas inti, control otot panggul, tungkai bawah, dan system vestibular dan visual. Keseimbangan dapat dibagi menjadi dua yaitu keseimbangan statis dan dinamis(Kisner, Caroly., 2018)Namun dalam aktivitas lompat jauh terutama pada fase mendarat maka keseimbngan dinamis yang sangat berperan.

Menurut Winter D, Keseimbangan adalah istilah umum yang menjelaskan kedinamisan postur tubuh untuk mencegah seseorang terjatuh(Risangdiptya \& Ambarwati, 2016). Keseimbangan adalah kemampuan tubu untukmelakukan reaksi atas setiap perubahan posisi tubuh. Sehingga tubuh tetap stabil dan terkendali. Dimana keseimbangan dapat diartikan sebagai kemampuan untuk mengontrol pusat massa tubuh atau pusat gravitasi terhadap titik atau bidang tumpu (Risangdiptya \& Ambarwati, 2016). Keseimbangan dinamis adalah kemampuan untuk mempertahankan keseimbangan tubuh ketika melakukan berbagai gerakan seperti ketika sedang jalan, lari, lompat, loncat atau berpindah dari satu titik ke titik lainya dalam satu ruangan.Keseimbangan dibutuhkan untuk mempertahankan posisi dan stabilitas ketika bergerak dari satu posisi ke posisi yang lain.(Wijianto.,Dewangga \& Batubara, 2019). Gerakan berjalan, lari atau berpindah dari satu titik ke titik yang lainya sangat memerlukan keseimbangan dinamis(Nala, 2011)

Keseimbangan adalah kemampuan tubuh untuk mengontrol pusat massa tubuh dengan bidang tumpu, keseimbangan dipengaruhi oleh sistemin formasi sensoris (visual, vestibular dan somatosensoris), respon otot-otot yang sinergis,kekuatan otot, system adaptif dan lingkup gerak sendi (Putu et al., 2018) Keseimbangan sebagai kemampuan untuk mengontrol pusat masa tubuh atau pusat gravitasi terhadap titik atau bidang tumpu dan dapat diasumsikan sebagai sekelompok reflek yang memicu pusat keseimbangan. Keseimbangan merupakan kemampuan untuk mempertahankan pusat gravitasi tubuh (center of gravitasi). Dan kemampuan sendi untuk membantu gerak tubuh dan mengarahkan gerakan terutama saat gerakan yang memerlukan keseimbangan. Dalam aktivitas fisik dan olahraga selalu dihadapkan kemungkinan terjadinya cedera, cedera ini akan berdampak pada gangguan aktivitas fisik, psikis dan prestasi. Bagian anggota tubuh yang sering mengalami cedera adalah pada bagian sendi pergelangan kaki. Cedera (Sumartiningsih, 2012). Ini akan berdampak terhadap keseimbangan pada gerakan mendarat pada lompat jauh.

Keseimbangan merupakan tugas control motorik kompleks yang melibatkan deteksi dan integrasi informasi sensorik, dimulai sejak sejak informasi keseimbangan tubuh akan ditangkap oleh reseptor vestibular, visual dan proprioseptik. Keseimbangan tubuh dipengaruhi oleh system 
indra yang terdapat di tubuh manusia bekerja secara bersamaan jika sala satu system mengalami gangguan maka akan terjadi gangguan keseimbangan pada tubuh. pada waktu seseorang berdiri atau berjalan goyang atau sempoyon (Syaifuddin, 2017). Sehingga control keseimbangan memerlukan interaksi system saraf, musculoskeletal dan efek kontekstual dari lingkungan (Kisner, Caroly., 2018) keseimbangan melibatkan berbagai gerakan disetiap segmen tubuh dengan didukung oleh sistem muskuloskeletal dan bidang tumpu.(Fatarudin Rois, 2018)

Kurangnya tingkat keseimbangan dapat diperbaiki dengan latihan keseimbangan yang spesifik atau latihan stabilitas. Terdapat banyak bentuk latihan yang dapat untuk meningkatkan keseimbangan dinamis atlet lompat jauh salah satu bentuk latihan keseimbangan yaitu: latihan keseimbangan Keseimbangan dapat dilatih dengan ankle balance strategy exercise.Ankle Balance Strategy Exercise merupakan latihan yang menggambarkan kontrol goyangan postural dari ankle dan kaki. Gerakan pusat gravitasi tubuh pada ankle strategy dengan membangkitkan putaran ankle terhadap permukaan penyangga dan menetralkan sendi lutut dan sendi panggul untuk menstabilkan sendi proximal. Keseimbangan merupakan interaksi yang kompleks dari integrasi sistem sensorik dan muskuloskeletal (otot, sendi, dan jaringan lunak lain)(Adenikheir, 2019)

Dengan memberikan latihan ankle balance strategy exercise dapat meningkatkan kemampuan ankle dan control gerakan dari tibia saat digunakan untuk menumpu.Kemampuan dari ankle strategy merupakan salah satu reaksi tubuhdalam mempertahankan keseimbangan (balance strategy). Balance strategy merupakan pola gerakanatau adaptasi dari otot sebagai hasil darimekanisme umpanbalikpada saat melakukan pembelajaran gerak. Dengan demikian memberikan latihan ankle balance strategy exercise merupakan pembebanan pada tungkai yang digunakan menumpuakan meningkatkan stabilisasi pada sendi ankle sehingga keseimbangan terjaga (Singh et al., 2016).

Dari paparan dan kajian teori maka peneliti tertarik untuk melakukan penelitian mengenai keseimbangan pada atlet lompat jauh pada fase mendarat membutuhkan stabilitas ankle untuk menjaga pergerakan pada saat menumpu dengan memberikan latihan ankle balance strategy exercise dalam meningkatkan keseimbangan pada Siswa putra peserta ekstrakurikuler lompat jauh di SMK N 1 Denpasar.

\section{METODE}

Penelitian ini merupakan penelitian jenis quasi Eksperimental dengan rancangan penelitian One GroupPre-Test and Post-TestDesign.Dengan bentuk rancangan penelitian sebagai berikut:

$$
\text { O1 X O2 (Sugiyono, 2018) }
$$

Penelitian ini dilakukan di lapangan Lumintang Denpasar pada bulan Mei - Juni 2019. Metode pengambilan sampel yang digunakan adalah Non-Probability Sampling denganjenis Purposive Sampling dimana terdapat pertimbangan tertentu yang telah dibuat oleh peneliti yaitu berdasarkan kriteria inklusi, kriteria eksklusi,dan kriteria dropout. Pada penelitian ini jumlah sampel penelitian 10 orang yang berasal populasi siswa peserta ekstrakurikuler lompat jauh SMK N1 Denpasar.

Keseimbangan diukur dengan Standing Strok Test(SST), standing strork test merupakan gold standart tes keseimbangan usia 15 - 30 tahun (Risangdiptya \& Ambarwati, 2016). Data dianalisis dengan menggunakan SPSS 20, uji statistik yang dilakukan meliputi: Uji Statistik Deskriptif, Uji Normalitas dengan Saphiro Wilk Test, dan Uji Hipotesis dengan uji paired sample t-test (Sugiyono, 2011)atau uji sampel berpasangan. Dengan tarap nilai signifikan $\mathrm{p}<0,05$ dianggap bermakna. 


\section{HASIL DAN PEMBAHASAN}

\section{Hasil}

Dari hasil penelitian ini dapat dipaparkan deskripsi data karakteristiksubjekpenelitian yang meliputiumursampelpenelitianserta distribusi nilai keseimbangan sebelum dan sesudah pemberian latihan, hasilpengukuran keseimbangan sebelum dan sesudah diberi latihan Ankle Balance Strategy Exercise, yang kemudian hasil-hasil tersebut diuji secara statistic untuk melihat apakah dengan pemberian latihan berupa Ankle Balance Strategy Exercise dapat meningkatkan keseimbangan siswa putra peserta ekstrakurikuler lompat jauh di SMKN1Denpasar.

Tabel 1. Karakteristik Umur Sampel Penelitianpada siswa putra peserta ekstrakurikuler lompat jauh di SMK N 1 Denpasar

\begin{tabular}{lccc}
\hline No & Usia (Tahun) & Frekuensi & Presentase (\%) \\
\hline & 16 & 5 & $50 \%$ \\
1 & 17 & 3 & $30 \%$ \\
2. & 18 & 2 & $20 \%$ \\
3. & & & \\
\hline Total & 10 & $100 \%$ \\
\hline
\end{tabular}

Berdasarkan table 1 di atas, karakteristik sampel dilihat dari umur, maka diketahui bahwa sampel berusia 16 tahun berjumlah 5 orang sampel dengan presentase $50 \%$, sampel berusia 17 tahun berjumlah 3 orang dengan presentase 30\% dan sampel berusia 18 tahun berjumlah 2 orang dengan presentase $20 \%$. Sehingga hal ini menunjukan mayoritas sampel penelitian berusia16 tahun.

Tabel 2. Distribusi Nilai Keseimbangan Sebelum Pemberian Latihan Ankle balance Strategy Exercisepada siswa putra peserta ekstrakurikuler lompat jauh di SMK N 1 Denpasar

\begin{tabular}{|c|c|c|}
\hline Tingkat Keseimbangan & Frekuensi & Presentase (\%) \\
\hline $\begin{array}{l}>51 \\
37-50 \\
15-36 \\
5-13 \\
0-4\end{array}$ & $\begin{array}{l}0 \\
0 \\
7 \\
3 \\
0\end{array}$ & $\begin{array}{r}0 \% \\
0 \% \\
70 \% \\
30 \% \\
0 \%\end{array}$ \\
\hline Total & 10 & 100 \\
\hline
\end{tabular}

Berdasarkan tabel 2 diatas, dapat diketahui bahwa hasil pre-intervensi diperoleh nilai keseimbang15-36 detik sebanyak 7 orang sampel dengan persentase $70 \%$ dan nilai keseimbangan 5-13 detik sebanyak 3 orang sampel dengan persentase $30 \%$. 
Tabel 3. Distribusi Nilai Keseimbangan Sesudah Pemberian Latihan Ankle balance Strategy Exercise pada siswa putra peserta ekstrakurikuler lompat jauh di SMK N 1 Denpasar

\begin{tabular}{ccc}
\hline $\begin{array}{c}\text { Tingkat } \\
\text { Keseimbangan }\end{array}$ & Frekuensi & Presentase (\%) \\
\hline$>51$ & 0 & $0 \%$ \\
$37-50$ & 0 & $0 \%$ \\
$15-36$ & 10 & $100 \%$ \\
$5-13$ & 0 & $0 \%$ \\
$0-4$ & 0 & $0 \%$ \\
\hline Total & & 100 \\
\hline
\end{tabular}

Pada table 3 . diatas, hasil menunjukan adanya peningkatan keseimbangan pada siswa peserta ekstrakurikuler lompat jauh SMK N1 Denpasar. Dilihat dari nilai pretest yang menunjukan adanya nilai yang kurang sedangkan pada posttest semua nilai menunjukan sedang.

Tabel 4. Hasil Uji Deskriptif Keseimbangan Pre- Intervensi dan Post -Intervesisiswa putra peserta ekstrakurikuler lompat jauh di SMK N 1 Denpasar

\begin{tabular}{lccccc}
\hline Var. & Mean & SD & Min & Max & Presentase $(\%)$ \\
\hline Nilai Pretes & 15,6 & 1,712 & 13 & 18 & 20,51 \\
\hline Nilai Post-test & 18,8 & 1,751 & 19 & 16 & 21 \\
& & & & & \\
\hline
\end{tabular}

Berdasarkan tabel 4 diatas, bahwa nilai rata-rata kesembangan pada pre-intervensi memperoleh hasil 15,6 dengan nilai terendah adalah 13 dan nilai tertinggi adalah 18 , sedangkan nilai rata-rata keseimbangan post- intervensi memperoleh hasil 18,8, dengan nilai terendah adalah 16 dan nilai tertinggi21. Pada pengukuran post-intervensi, standar deviasi memperoleh hasil 1,712. Pada tabel diatas menunjukkan perubahan mean (rata- rata) keseimbangan sampel pre-intervensi dan post-intervensi dan nilai perubahan sebesar3,2. Dan presentase peningkatan keseimbangan pre- intervensi dan post-intervensi di dapatkan sebesar $20,51 \%$.

Tabel 5. Hasil Uji Normalitas Keseimbangan siswa putra peserta ekstrakurikuler lompat jauh di SMK N 1 Denpasar

\begin{tabular}{llccc}
\hline Data & Df & Shapiro Wilk & $\mathrm{p}$ & Keterangan \\
\hline Pre test & 10 & & 0,591 & Normal \\
Post-test & 10 & 0,473 & Normal
\end{tabular}

Data hasil pengukuran keseimbangan siswa putra peserta ekstrakurikuler lompat jauh di SMK N 1 Denpasar, maka data sampel pre-intervensidan post-intervensi diuji normalitas datanya dengan metode Shapiro-Wilk. Data yang diuji dikatakan normal jika $(p>0,05)$, sebaliknya data yang diuji dikatakan tidak normal jikap $(p<0,05)$. Berdasarkan Tabel 5 diatas, hasil uji normalitas pengukuran keseimbangan menggunakan uji Shapiro -Wilk diperoleh nilai signifikanya itu pada pre-intervensip $=0,591$ dan post-intervensi $p=0,473$. Dari hasil uji normalitas dengan Shapiro - Wilk, data pengukuran keseimbangan pre-intervensi berdistribusi normal karena nilai 0,591 lebih besar dari 0,05 yang berarti $p>0,05$ dan data post-intervensi berdistribusi normal karena nilai 0,473 lebih besar dari 0,05 yang berarti $p$ 
$>0,05$. Maka data pre-intervensi dan post-intervensi siswa putra peserta ekstrakurikuler lompat jauh di SMK N 1 Denpasar berdistribusi normal.

Tabel 6. Hasil Uji Hipotesis t-test Berpasangan Keseimbangan siswa putra peserta ekstrakurikuler lompat jauh di SMK N 1 Denpasar

\begin{tabular}{lcccc}
\hline Hasil & Df & $t_{\text {hitung }}$ & P & Keterangan \\
\hline $\begin{array}{l}\text { Keseimbangan Pre-test } \\
\text { Post-test }\end{array}$ & 9 & $-3,2$ & 0,000 & Signifikan \\
\hline
\end{tabular}

Uji hipotesis yang digunakan adalah $t$-test berpasangan (paired $t$-test). Latihan Ankle Balance Strategy Exercise dapat dikatakan memberikan pengaruh terhadap keseimbangan apabila dalam uji $t$-test berpasangan, nilai $p<0,05$. Berdasarkan tabel di atas, hasil uji hipotesis dengant-test berpasangan menghasilkan nilai signifikan (2tailed) yaitu $p=0,000$ yang artinya $\mathrm{p}<0,05$ sehingga dapat dikatakan bahwa terdapat pengaruh latihan ankle balance strategy exercise untuk meningkatkan keseimbangan siswa putra peserta ekstrakurikuler lompat jauh di SMKN 1Denpasar.

\section{Pembahasan}

Berdasarkan hasil uji analisis data berupa uji normalitas data dan uji hipotesis didapatkan bahwa data hasil pengukuran keseimbangan menggunakan uji Saphiro Wilk menunjukkan nilai $p$ pada pre- intervensi yaitu 0,591 dan post-intervensi 0,473 menunjukkan nilai signifikan $(p>0,05)$ yang berarti data berdistribusi normal. Sementara pada uji hipotesis dengan $t$-tes $t$ berpasangan di dapatkan nilaip $=0,000$ menunjukkan bahwa nilai signifikan $(p<0,05)$ yang berarti pemberian latihan anklebalance strategy exercise berpengaruh terhadap peningkatan keseimbangan siswa putra ekstrakurikuler lompat jauh di SMKN 1 Denpasar.

Lompat jauh merupakan olahraga prestasi yang sering diperlombakan untuk anak-anak sekolah. Padadasarnya olahraga ini memiliki 4 teknik yang membutuhkan keseimbangan tubuh dari fase awalan hingga fase mendarat. Keseimbangan merupakan suatu kemampuan tubuh untuk merespon reaksi atas setiap pergerakan yang merubah posisi tubuh, sehingga tubuh akan tetap stabil dan terkandali. Dalam olahraga lompat jauh jika atlet lompat jauh tidak memiliki keseimbangan maka stabilitas penggerak tidak dapat bekerja secara stabil dan dapat berisiko tinggi yaitu seperti cedera sejalan dengan penelitian yang dikemukakan oleh (Thomson, 2009).

Keseimbangan dilatih dengan menggunakan latihan Strategy Exercise.Latihan anklebalance strategy exercise akan menimbulkan kontraksi otot. Kontraksi otot yang berulang akan menstimulus kontrol saraf motoric dan sensorik. Pada awal pelatihan, neuron berada pada keadaan terfasilitasi, yaitu besarnya potensial membran mendekati ambang dengan tujuan untuk peletupan dibandingkan keadaan normal tetapi belum cukup mencapai batas peletupan. Pelatihan ankle balance strategy exercise yang dilakukan dengan frekuensi tiga kali seminggu selama empat minggu berturut-turut dapat memberikan efek berupa adaptasi neural yang meliputiantara lain: sumasi spasial dan sumasi temporal pada system saraf.Adaptasi neural tersebut dapat menimbulkan sumasi serabut multiple yaitu adanya peningkatan jumlah unit motorik yang berkontraksi dengan cara bersamasama.Meningkatnya jumlah unit motorik, maka akan terjadi peningkatan kekuatan otot (Apriani, N.P.R., Tianing \& Grandhi, 2015).

Pada saat dilakukan ankle balance strategy exercise, juga akan merangsang kerja proprioseptif pada sistem somatosensorik. Informasi proprioseptif disalurkan ke otak melalui kolumna dorsalis medulla spinalis. Sebagian besar input proprioseptif menuju serebelum. Impuls yang dating dari alat indra adalah ujung- ujung saraf yang beradaptasi disinovial dan ligamentum. Impuls dari alat indra ini dari reseptor pada kulit dan jaringan lain serta otot yang diprosesdi korteks yang akan memberikan kesadaran posisi tubuh saat bergerak untuk mencapai dan mempertahankan keseimbangan tubuh (Magdalena, 2017) 
Terbentuknya proprioseptif yang baik maka informasi mengenai posisi tubuh terhadap kondisi lingkungan disekitarnya (eksternal) dan posisi antara segmen tubuh (internal) yang diterima oleh serebellum akan lebih baik,informasi tersebut akan digunakan oleh tubuh untuk mempertahankan keseimbangan(Swandari et al., 2015).

\section{SIMPULAN DAN SARAN Simpulan}

Berdasarkan hasil penelitian yang telah dilakukan dapat disimpulkan bahwa pemberian latihan ankle balance strategy exercise meningkatkan keseimbangan siswa putra peserta ekstrakurikuler lompat jauh di SMKN 1 Denpasar.

\section{Saran}

Berdasarkan hasil penelitian maka dapat disarankan bagi pelatih dan atlet untuk meningkatkan prestasi lompat jauh, maka dalam sesi Latihan diharapkan pelatih memperhatikan dan meningkatkan kualitas keseimbangan para atlenya.

\section{DAFTAR PUSTAKA}

Adenikheir, A. (2019). MENARA IImu Vol. XIII No.2 Januari 2019. Menara IImu, XIII(2), 102114.

Apriani, N.P.R., Tianing, N. W., \& Grandhi, P. A. (2015). Pemberian Pelatihan balance Strategy Exercise Lebih baik Dari pada Pelatihan Core Stability Exercise Dalam Meningkatakan keseimbangan Dinamis Pada Lansia Di Banjar Bumi shanti, desa Dauh Puri Kelod, Kecamatan denpasar Barat. Skripsi. Denpasar Universitas . Artikel Skripsi.

Fatarudin Rois, R. W. (2018). Manfaat Ankle Strategy Exercise Terhadap Keseimbangan Statis Pada Lansia di Posyandu Lansia Ngudi Waras Dusun Bugel Sukoharjo. The 7th University Research Colloqium 2018 STIKES PKU Muhammadiyah Surakarta, 2012, 392-399.

Kisner, Caroly., C. L. A. (2018). Intisari Terapi Latihan Buku Praktik Klinik. Buku Kedokteran EGC.

Magdalena, I. (2017). Pengaruh core Stability Exercise Terhadap Risiko Jatuh Pada Lanjut Usia Di Panti Sosial tresna werdha Gau Mabaji Gowa.Skripsi Makasar: Universitas Hasanudin. 2017.

Meriyanto, D., Nurrochmah, S., \& Heynoek, F. P. (2016). Hubungan Antara Kekuatan Otot Tungkai Dengan Kemampuan Lompat Jauh. Jurnal Pendidikan Jasmani. https://doi.org/10.17977/PJ.V26l1.7737.G3555

Nala. (2011). Prinsip Pelatihan Fisik Olahraga (Adiputra (ed.); Pertama). Udayana University Press.

Putu, N., Sulistyawati, D., Ayu, I., \& Suadnyana, A. (2018). DAPAT MENINGKATKAN KESEIMBANGAN DINAMIS PADA ANAK DENGAN AUTISM SPECTRUM DISORDER ( $A S D$ ) pada anak adalah Autism Spectrum Disorder ( $A S D$ ). ASD adalah gangguan Berdasarkan data Center for pada tingkat kemandirian anak . Pada dengan ASD dapat dilihat dari. 2(November).

Risangdiptya, G., \& Ambarwati, E. (2016). Perbedaan Antara Keseimbangan Tubuh Sebelum Dan Sesudah Senam Pilates Pada Wanita Usia Muda. Jurnal Kedokteran Diponegoro, 5(4), 911-916.

Sehuddin. (2017). Pengaruh Keseimbangan , Daya Ledak Tungkai Dan Motivasi Terhadap Kemampuan Lompat Jauh Pada Siswa SMAN 11 Maros Baru Kabupaten Maros. SPORIIVE: Journal of Physical Education, Sport and Recreation, 1(September).

Sidik. (2010). Mengajar dan Melatih Atletik (Wardan (ed.)). PT Rosdakarya Offset. 
Singh, S., Handa, A., \& Khanna, T. (2016). Comparison of Individual and Combined Effects of Ankle Strengthening and Proprioception Training on Balance Performance in Elderly Women. 5(1), 56-62. https://doi.org/10.9790/1959-05125662

Sugiyono. (2011). STATISTIKA untuk PENELITIAN. CV ALFABETA.

Sugiyono. (2018). METODE PENELITIAN PENDIDIKAN PENDEKATAN KUANTITATIF, KUALITATIF,DAN R\&D (27th ed.). ALFABETA.

Sumartiningsih, S. (2012). Cedera Keseleo pada Pergelangan Kaki (Ankle Sprains). Media IImu Keolahragaan Indonesia, 2(1).

Swandari, N. M. ., Nurmawan, P. ., \& Sundari, L. P. . (2015). Pelatihan Proprioseptif Efektif dalam Meningkatan Keseimbangan Dinamis pada Pemain Sepak Bola dengan Functional Ankle Instability di SSB Pegok .Denpasar: Universitas Udayana.

Syaifuddin. (2017). ANATOMI FISISIOLOGI Kurikulum Berbasis Kompetensi (Sk. Monika Ester (ed.); 4th ed.). EGC.

Thomson, P. (2009). the Official IAA Guides To Teaching Athletic. The International Association of Athletics Federation.

Wijianto.,Dewangga, M. W., \& Batubara, N. (2019). Resiko Terjadinya Gangguan Keseimbangan Dinamis dengan Kondisi Forward Head Posture ( FHP ) pada Pegawai Solopos. GASTER, 17(2), 217-230. 